\title{
SOCIAL DIALOGUE IN THE CONDITIONS OF NEW TECHNOLOGICAL TRANSFORMATION
}

\author{
Cristina DIMA ${ }^{a *}$, Ghenadie CIOBANU ${ }^{b}$, Daniel MOISE ${ }^{c}$, \\ Oana Matilda SABIEd, Ștefan Gabriel BURCEA ${ }^{e}$ \\ ${ }^{a, c, d, e}$ Bucharest University of Economic Studies, Romania \\ ${ }^{b}$ INCSMPS, Bucharest, Romania
}

\begin{abstract}
The development of new technologies worldwide has radically changed contemporary society, countries' economies, industries, agriculture, services, education First of all, it is about the digital revolution that has changed and continues to bring changes in society and the economy, but also other technological revolutions such as biotechnologies, nanotechnologies, robotics, etc. Although technological impact adds value to human activity at all levels, there are many primarily social problems that arise in the labor market that need to be addressed today in order to have the right direction for implementing development strategies and policies.

The purpose of this paper is to capture developments and debates in the national policy framework to address digital challenges and the implementation of new technologies and to map their impact on the business environment, employment and employment working conditions.
\end{abstract}

KEYWORDS: social dialogue, technological transformation, digitization, nanotechnology

\section{INTRODUCTION}

Both the transformations of recent years, the problems we have faced in recent years, and the current epidemiological crisis clearly demonstrate the importance of application in practical activity and the implementation of new technologies in everyday life in economic activity. It is primarily about adapting digital technologies, but also other technologies such as biotechnology, nanotechnology and other innovations in modern science and technology that would ensure smart, sustainable and inclusive growth, in line with the objectives of the 2020 Strategy (European Comission, 2010): "An Innovation Union", "Youth on the Move", "A Digital Agenda for Europe", "A Resource Efficient Europe" - "An Industrial Policy for the Globalization Era" - "An Agenda for New Skills and new jobs" - "European Platform against Poverty”. Given that Romania "needs a change in the current development paradigm to meet the challenges of the 21st century", both Romania and the EU need to redesign their medium and long-term priorities to achieve the 2030 Agenda objectives for Sustainable Development”. Romania registers a high share of people suffering from severe material deprivation, compared to the EU average (United Nations, 2015).

Agriculture occupies an important place in the Romanian economy and has considerable development prospects in the European context, due to the favorable soil and climate conditions and the potential in the field of organic production. Organic farming is a dynamic system in Romania, registering an upward trend lately.

Renewable energy and energy efficiency - The targets set at EU level for 2020, regarding the contribution of energy policies to reducing the impact of climate change, have been achieved in advance by Romania (European Comission, 2010).

\footnotetext{
* Corresponding author. E-mail address: cristina.dima@man.ase.ro
} 
Sustainable industrialization - Romania needs an industry with minimal environmental impact to mitigate climate change, addressing challenges such as reducing industrial greenhouse gas emissions, energy efficiency and resource use through cleaner technologies, green industrial approaches and increased environmental awareness programs.

Research and innovation - Romania is positioned in the category of modest innovators, occupying for several years one of the last places in Europe, by the low share of spending on research development - innovation (RDI), constantly below 0.5\% of GDP (Romanian Government, 2018).

Smart city - A smart and sustainable city is an innovative city that, through the use of information and communication technology, data collected from equipment used in the provision of services.

Industrial policy - The new EU approach places greater emphasis on competitiveness in a global context, by ensuring the sustainability of production and consumption, increasing the efficiency of the use of material resources, revitalizing high value-added manufacturing industries and balancing the service sector, which has seen rapid development in recent decades (Romanian Government, 2018). Resource productivity - Resource productivity is measured by the value in euros of products obtained from the processing of one kilogram of raw materials. Romania continues to be in an inferior position, registering even a setback compared to the European average (Romanian Government, 2018). The new digital, intelligent, robotic and Nano technological processes will have a massive impact on the development of all major economies, including the management of economic networks, and of all industries and services. They will also reach the level of jobs that will bring you both positive and negative transformations. And then it is necessary from the design of new production systems, from the design and creation of new jobs and the destruction of old places to take into account the social aspects in which social dialogue can have an important place and the process of new technological transformations. a new economy.

\section{THE IMPACT OF THE INNOVATIVE PROCESS ON COMPANIES IN ROMANIA}

According (Muñoz-de-Bustillo Llorente, 2020) we could mention the disappearance of employment in full as an objective of economic policy, the deregulation of the labor market in search of more efficient labor markets - which would lead lowering unemployment, globalization and the growth of a global labor market and the new technological revolution related to the use of information and communication technology (ICT) and the digital revolution. In the paper, the author analyzes the measures in which the digitalization of the economy transforms the world of work, as well as the role of social dialogue, now and in the future, to help improve the governance of these changes, minimizing their negative impact on labor markets and stimulating their positive effects. Among the factors of change, we mention: (1) An old knowledge of political economy, the debate on the employment implications of the introduction of machines has taken place at least since the third edition of Ricardo's Principles of Political Economy and Taxation in 1821; (2) The Internet of Things can make it possible to transform entire production processes into digital processes, contributing to the automation of production at unprecedented levels, as well as to the achievement of economic sectors. (3) The possibilities generated by new digital technologies to develop a new model of the company, the so-called "platform", which maximizes the potential to coordinate computerization and algorithms to act as a pure intermediary between customers of a given good or service and workers who I produce it (Muñoz-de-Bustillo Llorente, 2020).

We intend to start with the analysis on the evolution of the innovation process in Romanian enterprises, from a statistical point of view, we can present enterprises with product and / or process innovation by activities, size classes, by macro-regions and development regions. In the Romanian economy the evolution of the innovation process in enterprises from a statistical point of view we can present the Enterprises with product and / or process innovation by activities, size classes, by macro-regions and development regions 
Table 1. Enterprises with product and/or process innovation by activities, size classes, by macro-regions and development regions, INO102A ${ }^{\dagger}$

\begin{tabular}{|c|c|c|c|c|c|c|c|c|c|}
\hline $\begin{array}{c}\text { Macroregions and } \\
\text { development regions }\end{array}$ & $\begin{array}{c}\text { Size } \\
\text { classes } \\
\text { and } \\
\text { economic } \\
\text { activities }\end{array}$ & 2002 & 2004 & 2006 & 2008 & 2010 & 2012 & 2014 & 2016 \\
\hline TOTAL & Total & 3983 & 5171 & 6013 & 5907 & 3763 & 1806 & 1840 & 1556 \\
\hline- & small & 2137 & 2851 & 3523 & 3787 & 2386 & 1034 & 1258 & 1030 \\
\hline - & medium & 1183 & 1597 & 1836 & 1520 & 936 & 506 & 371 & 373 \\
\hline- & large & 663 & 723 & 654 & 600 & 441 & 266 & 211 & 153 \\
\hline- & Industry & 2907 & 3489 & 3789 & 3751 & 2381 & 1141 & 937 & 858 \\
\hline- & Services & 1076 & 1682 & 2224 & 2156 & 1382 & 665 & 903 & 698 \\
\hline $\begin{array}{l}\text { NORTH-EAST } \\
\text { region }\end{array}$ & Total & 607 & 688 & 862 & 791 & 461 & 194 & 99 & 186 \\
\hline $\begin{array}{c}\text { SOUTH- } \\
\text { MUNTENIA region }\end{array}$ & Total & 391 & 458 & 573 & 642 & 439 & 168 & 132 & 77 \\
\hline $\begin{array}{l}\text { SOUTH-WEST- } \\
\text { OLTENIA region }\end{array}$ & Total & 247 & 216 & 235 & 227 & 151 & 25 & 44 & 49 \\
\hline $\begin{array}{c}\text { NORTH-WEST } \\
\text { region }\end{array}$ & Total & 440 & 675 & 909 & 717 & 539 & 154 & 150 & 274 \\
\hline WEST region & Total & 291 & 354 & 329 & 413 & 209 & 64 & 75 & 63 \\
\hline $\begin{array}{l}\text { SOUTH-EAST } \\
\text { region }\end{array}$ & Total & 395 & 923 & 1307 & 1154 & 663 & 545 & 440 & 336 \\
\hline CENTER region & Total & 764 & 712 & 808 & 934 & 443 & 276 & 224 & 164 \\
\hline $\begin{array}{c}\text { BUCHAREST - } \\
\text { ILFOV region }\end{array}$ & Total & 848 & 1145 & 990 & 1029 & 858 & 380 & 676 & 407 \\
\hline $\begin{array}{l}\text { Innovators only total } \\
\text { product }\end{array}$ & Total & 582 & 472 & 525 & 710 & 635 & 351 & 313 & 430 \\
\hline $\begin{array}{c}\text { Innovators with } \\
\text { unfinished and or } \\
\text { abandoned activities, } \\
\text { totally }\end{array}$ & Total & 20 & 35 & 43 & 159 & 132 & 115 & 311 & 130 \\
\hline $\begin{array}{l}\text { Process innovators } \\
\text { only, total }\end{array}$ & Total & 413 & 1203 & 1169 & 1965 & 955 & 706 & 511 & 478 \\
\hline $\begin{array}{l}\text { Product and process } \\
\text { innovators, total }\end{array}$ & Total & 2968 & 3461 & 4276 & 3073 & 2041 & 634 & 705 & 518 \\
\hline
\end{tabular}

Source: adapted from INSSE

Enterprises with product and / or process innovation are enterprises that have launched new or significantly improved products (goods or services) or processes. Innovations are based on the results of technological developments, new combinations of existing technologies or the use of other knowledge required by the enterprise.

Product innovation means the placing on the market of a new or significantly improved good or service, in terms of its characteristics, friendly use, components or subsystems.

\footnotetext{
† INSSE, Enterprises with product and/or process innovation by activities, size classes, by macro-regions and development regions, INO102A, www.insse.ro/tempo
} 
Process innovation corresponds to the implementation of a production process, a distribution method or a support activity, new or significantly improved. Unfinished or abandoned innovation is the innovative activity carried out by the enterprise, for the introduction or development of new or significantly improved products (goods or services) or for the implementation of new or significantly improved processes or processes, which has not been completed or abandoned.

\section{RESEARCH METHODOLOGY}

This paper aims to identify and analyze the opinions of the authors of the literature, of the reports made by public and private institutions worldwide, on social dialogue in the conditions of technological transformations.

\subsection{High-tech statistics - employment}

From the study High-tech statistics - employment, (Eurostat Statistics Explained, 2019) we present the evolution of employment in high-tech sectors, employment in technological and knowledgeenhanced sectors at national level, at EU 28, EU-27 level, compared to Romania, but and countries with a comparable level of development in socio-economic development and European integration.

Table 2. Evolution of employment in technology and knowledge-intensive sectors at the national level (2010-2019)

\begin{tabular}{|l|c|c|c|c|c|c|}
\hline GEO/TIME & 2010 & 2012 & 2014 & 2016 & 2018 & 2019 \\
\hline $\begin{array}{l}\text { European Union - 27 } \\
\text { countries (from 2020) }\end{array}$ & $186.516,6$ & $185.805,8$ & $187.237,7$ & $192.143,8$ & $197.478,5$ & $199.437,0$ \\
\hline $\begin{array}{l}\text { European Union - 28 } \\
\text { countries (2013-2020) }\end{array}$ & $215.558,8$ & $215.289,7$ & $217.771,7$ & $223.649,0$ & $229.667,5$ & $231.963,6$ \\
\hline Bulgaria & $3.072,8$ & $2.931,0$ & $2.977,7$ & $3.014,0$ & $3.148,0$ & $3.228,6$ \\
\hline Czechia & $4.875,0$ & $4.883,7$ & $4.964,2$ & $5.127,3$ & $5.280,8$ & $5.288,0$ \\
\hline Estonia & 568,0 & 614,9 & 624,8 & 644,6 & 664,7 & 671,3 \\
\hline Croatia & $1.683,0$ & $1.558,0$ & $1.561,6$ & $1.587,1$ & $1.650,5$ & $1.674,9$ \\
\hline Cyprus & 392,4 & 383,2 & 361,5 & 361,3 & 398,7 & 414,4 \\
\hline Latvia & 850,7 & 875,6 & 884,6 & 893,3 & 909,4 & 910,0 \\
\hline Lithuania & $1.246,2$ & $1.272,8$ & $1.314,9$ & $1.354,2$ & $1.367,1$ & $1.371,9$ \\
\hline Hungary & $3.732,4$ & $3.827,2$ & $4.100,8$ & $4.351,6$ & $4.469,5$ & $4.512,1$ \\
\hline Poland & $15.432,4$ & $15.549,8$ & $15.826,1$ & $16.163,3$ & $16.456,5$ & $16.431,1$ \\
\hline Romania & $8.712,8$ & $8.605,1$ & $8.613,7$ & $8.448,8$ & $8.688,5$ & $8.680,3$ \\
\hline Slovenia & 960,5 & 919,3 & 909,6 & 912,6 & 976,9 & 980,3 \\
\hline Slovakia & $2.316,5$ & $2.328,4$ & $2.362,6$ & $2.491,3$ & $2.565,3$ & $2.581,6$ \\
\hline
\end{tabular}

Source: adapted from Eurostat Statistics Explained (2019)

35.3 million people were employed in the production sector in the EU-28, representing $15.4 \%$ of total employment. 2.4 million people were employed in the production of state-of-the-art technologies, representing 1.1\% of the total employees. 3\% of all jobs were employed in the field of high-tech knowledge (Eurostat Statistics Explained, 2019). The variation from country to country was different in the field of production and services of high technologies, in Cyprus, Latvia, Lithuania by $0.4 \%$, Ireland by $2.8 \%$. Regarding the relative importance of high-tech services in total, employment is observed in Ireland (5.3\%), Finland and Sweden (4.7\%, in both countries), Estonia (4.3\%) (Eurostat Statistics Explained, 2019). The lowest level is in Romania and Greece (2.2\% in both countries). The increase in high-tech production was observed in Lithuania, with a growth rate of $4.5 \%$, leading the following ten countries: Romania (4.3\%), Austria (2.3\%), Slovenia (2.3\%), Cyprus (2.2\%), Czech Republic (2.1\%), Estonia and Germany (both with 1.7\%), Hungary 
(0.7\%), Denmark (0.6\%) and Poland (0.2\%) \%) (Eurostat Statistics Explained, 2019). The average annual growth rate for employment in high-tech services was positive in 2008-2018. In the manufacturing sector, the average decrease was $0.8 \%$ per year - high-tech production (Eurostat Statistics Explained, 2019).

The best performing countries in terms of increasing the number of jobs in knowledge-intensive high-tech services were Estonia (5.4\%), Romania (4.5\%), Slovakia (4.1\%), as well as and Turkey (5.8\%) and Serbia (5.6\%). In knowledge-intensive high-tech services, the proportion of women (30.0\%) was lower than in the total services sector (54.3\%) (Eurostat Statistics Explained, 2019).

On the other hand, women were relatively strongly represented in Lithuania (39.7\%), Latvia (38.9\%), Bulgaria (38.1\%), Romania (35.6\%), as well as in Montenegro (46, 0\%) and Serbia (40.9\%) (Eurostat Statistics Explained, 2019).

In particular, computer programming, scientific research and development, telecommunications and related occupations still seem to attract more men than women.

\subsection{Bibliographic study on the international experience of social dialogue in the process of technological transformations}

In the paper Building Trust in a Changing World of Work, The Global Deal for Decent Work and Inclusive Growth Flagship (Global Deal, 2018) it is mentioned that the key elements of the global transaction and how it is supported Global Dialogue and work to achieve goals its general principles which are based on three key elements: 1 . Accelerating action. Partners are encouraged to make voluntary commitments that contribute to the vision of the global agreement for decent work and inclusive growth. 2. Increasing the knowledge base through capacity building and research. Therefore, knowledge about social dialogue and strong industrial relations is strengthened, as well as the identification of gaps in existing research.

According (Hanin, 2010a) the authors distinguish between classical Taylors managerial strategies (which involve increasing levels of micro supervision in order to intensify the work) and new innovations in cleaning machines and surveillance technology. The strong point of this book is that it combines the work of different researchers and, in this sense, offers different perspectives of the same object of analysis.

In the paper Social dialogue and the future of work Report of the ILO-AICESIS (International Labour Organization, 2018) the future of work offers some preliminary recommendations on how to strengthen their commitment. The conference led to a rich debate among government representatives, employers and workers, as well as experts from international organizations and other actors on how to support workers and businesses to enable them to adapt to the future world of work.

Dueñas Herrero (2019) claim that: The European Union has called on the European Commission, Member States and partner social societies to establish rules for an economic sphere that is deregulated or has a significant role, regulatory gaps: digitalization and the platform economy. The European Parliament has made recommendations setting out the social guidelines needed to regulate labor relations in collaboration platforms. Accepting changes in labor law requires overcoming untouched axioms that survive in contemporary economic thinking, such as those linking rigid labor regulations, delayed recovery from the economic crisis, rising unemployment, and others, to a lack of adaptation to labor regulation technology.

Opinion of the European Economic and Social Committee on the social dialogue for innovation in the digital economy (Ahtela, 2019) sets out the following conclusions and recommendations: (1) Innovation, is an important factor in the competitiveness, productivity and growth potential of enterprises and can improve the quality of work, stimulate the creation of new jobs, improve living standards. (2)

Digitization, together with other evolutionary phenomena, affects working conditions, the economic situation of workers and working life, tests the current structures and methods of management and management of enterprises, labor relations, scope and methods of social dialogue. (3) Knowledge- 
based work is already normal. Information technology and digitization allow the dissociation of time and space in relation to work. (4) The evolution towards a greater autonomy of the number of workers, tests the structures and the methods of management and management of the enterprises. (5) The EESC emphasizes the importance of ensuring an understanding of the benefits and challenges for workers as a result of the adoption of new approaches to workplace culture, job security and quality, working conditions, health, safety and training. (6) Social dialogue, collective bargaining between the social partners can be essential tools, if they are used from the beginning of the introduction of new technologies, in the spirit of trust between staff and management. (7). New forms of fragmented work, increasing the number of atypical workers require the involvement of these workers, through information and consultation, by adapting collective rights and provisions on working time and social rights. (8) The EESC supports the view on the likelihood of innovation, and increases it if strong work organization structures are linked to various forms of increased employee participation. (9) The relationship of trust between workers' representatives, trade unions and management, combined with the direct participation of workers in decision-making bodies, is associated with higher levels of performance and well-being. (10) Social partner initiatives at all levels of the administration (local, regional, national) will improve the productivity and well-being of workers at work, which is a necessary method to be promoted in a broad European context.

Vogel (2017) analyzes the evidence in the Czech Republic, Denmark, Germany, Italy and Spain that the social partners are closely involved in creating national strategies for managing digital change in the world of work. So far, this has been a high-level issue and there are only a few collective agreements or company contracts in this issue in these five countries.

Authors Oscar \& Miguélez (2013) mentions: "Studying the impact of crisis and crisis response policies on national tripartite social dialogue, collective bargaining, labor law in ILO member states and in the European Union (EU) and the role of social dialogue actors and institutions in this context. In the two decades leading up to the crisis, social dialogue in Spain played a key role, which was an important feature of industrial relations." Following the financial and debt crisis, important reforms and economic adjustments took place in Spain. Social dialogue as an instrument of socio-economic governance has been called into question for its legitimacy and effectiveness, the role of the Government in social dialogue has been reduced. First, fiscal constraints have limited the possibilities for involvement in mutually profitable forms of political exchange, there is a narrowing of the scope of tripartite agreements in a context of weak institutionalization of social dialogue. The work, organized in three sections. (1) Provides the economic, institutional and political context in which austerity measures have been implemented and pays particular attention to the structural imbalances that have characterized the Spanish economy. (2) Analyzes the development of social dialogue during periods of austerity and emphasizes the involvement of processes in labor market negotiation and collective bargaining reforms. (3) It discusses the impact of adjustment policies on the labor market, industrial relations and social dialogue. (4) Provides certain concluding observations and proposals on possible ways to revitalize the tripartite social dialogue. The role of social dialogue and the impact on adjustment have varied over time and across policy areas. The political process: Social dialogue and negotiated adjustment in times of austerity. 1. An overview of social dialogue in Spain- The tripartite social dialogue in Spain has gone through several stages, it has played a key role as a mechanism for socio-economic governance. 2. Overview of the evolution of social dialogue in the period 2008-2012. As mentioned above, two well-differentiated periods in terms of tripartite social dialogue can be differentiated from the beginning of the financial and economic crisis. 2. Social dialogue in the debt crisis and austerity governance, it is important to note the existence of the document that provided the general direction of the dialogue in content and form. 4. Economic and industrial policy in times of austerity: the role of social dialogue.

In Spain, for example, in 2010 it relied on revenue-raising measures with the aim of protecting basic social spending and protecting social assistance recipients from the effects of the crisis. 3. Labor market reforms in times of austerity: The role of social dialogue and collective bargaining. The economic crisis led to major changes in labor market regulation and employment policy in 2010, 
2011 and 2012. The regulatory mechanism chosen to deal with the impact of the economic crisis on the labor market was initially collective bargaining.

Author Mexi (2019) has shown that: "In recent years, the digital platform economy has been the most important in academic and policy discussions, as digital platforms and mobile "applications" such as Uber, Airbnb and TaskRabbit - which want to connect consumers, businesses and workers - have grown”. As pointed out by a number of international organizations and actors. Decent digitization, about creating opportunities for everyone to fully participate in a digital future, work that offers self-respect and dignity, security and equal opportunities, representation and voice. It is about promoting inclusive platform-based innovation, changing the needs of businesses and ensuring sustainable economic growth. Possible factors that allow the trend of social dialogue and collective bargaining in the platform economy: we can observe three types of active factors that are valid for further exploration and evaluation: (1) Existence of highly organized markets: enterprise and worker platforms will have more "incentives" to engage, negotiate directly in markets that are well organized and may put pressure, in particular, on platform companies coming to the negotiating table. (2) Sectors where the platforms are active and the degree of employee representation: whether a platform company will decide to negotiate or not is more likely to depend on whether the platform operates in sectors and industries where workers are already highly organized and unionized, as shows the examples of the cleaning and transport industries in several countries. (3) the tendency of some platforms to become more socially responsible: the motivation for voluntary agreements signed in the platform economy comes from the platform's desire to present itself as a "correct option". Decent digitization and the role of the social partners: In the context of extensive discussions about the future of digital work, it is also common, he pointed out, that along with difficult readjustments and transitions, there are new possibilities discovered and deployed, which can have a transformative impact. How social dialogue can contribute to a decent digiwork and a sustainable model of the platform's economy. Social dialogue can play a positive role, suggesting places to address the problematic aspects of the platform's digital work in common beneficial ways. ESC-SI and the platform economy: realizing the potential of social dialogue. ESCSI needs to put three key questions on their agenda: Will the digital platform remain a form of employment niche or is it a precursor to broader trends? How can companies and digital work workers in the platform economy have their interests represented in ESC-SI? And how can social dialogue be a complementary and flexible tool for regulating the labor market to foster an inclusive future of the digital work platform? According to the authors: "The social partners in the Czech Republic, Denmark, Germany, Italy and Spain are part of the national debates on digital change and its (future) impact on employees and businesses. National digital agendas or action plans are currently high-level issues and do not yet translate into sectorial or company-level implementation in all five countries. It is a challenging process; digitalization affects various dimensions of national economies and productions.

Sadovaia (2019) claim: As has happened many times in human history, technological changes, which are gradually accumulating, in an certain stage of development leads to a revolutionary change of the whole social reality. It happened in Europe during the industrial revolution. We are entering a new world, still little known, of social and technological innovations, which have already made our lives healthier, longer and more interesting and due to the emergence of digital infrastructure and technology, unified information, but at the same time the emergence of completely unknown risks and challenges.

According Hanin (2010b) the work of four main chapters that reflect the challenges of social dialogue at European and territorial level. An analysis is made of the evolution of social dialogue in Europe, especially in France, crossing two dimensions in full transformation: the European level with European works councils mainly and the territorial level with the local regulations on labor and employment that have been developed in the context of the decentralization of the administrative powers of the state. Three hypotheses guided research on new frameworks for social dialogue. The first hypothesis is that "the relevance of the space for collective bargaining and social 
dialogue depends less on the subject of this dialogue [...] than on the capacity of collective actors to structure themselves in this space and to take collective action" (p. 15). Authors (Lucas et. al., 2017) states that: "social robots establish a relationship with human users". In the paper, the authors explore the extent to which reporting can benefit conversations with robots and the circumstances that occur. Previous work has shown that agents who make conversational errors are less able to influence people than agents who do not make mistakes. Previous research has not taken into account additional factors, such as the "level of the relationship between person and robot". Building the relationship through social dialogue could mitigate the harmful effect of a robot's errors on influence. Authors (Invernizzi \& Foladori, 2010) consider that: "Research on the social implications of nanotechnology has hardly addressed the subject of work, despite the social importance of the subject. Based on an analysis of the characteristics of nanotechnology products that are already on the market, this study reflects that nanotechnology will have a significant impact on the distribution of jobs across sectors, the international division of labor and the qualification requirements for work." Therefore, there are destabilizing effects on employment at national and global level. The authors described how nanotechnology leads to job creation and destruction, changes in the sectoral distribution of labor, contributes to changes in the global spatial distribution of labor, and changes in job qualifications.

\section{CONCLUSIONS}

Although the roles and contributions of social dialogue in the traditional economy are well tested and have been widely documented worldwide, its potential does not contribute to addressing the challenges posed by the platform economy and sufficiently exploited digital work. Although it is difficult to assess the effectiveness of reforms due to the rapidly changing economic environment, some interviewees agreed that the 2010 agreement had a limited impact. In addition to the negative economic environment; one reason was the socialist government's fear of confrontation. strong opposition from the unions. This led to the unilateral approval of an extremely prudent reform plan, which did not have a real or very limited impact on shaping the evolution of the labor market. The attitude towards the importance of education and training, further training and retraining throughout professional life is beginning to apply in practice when it comes to deciding who has to pay for such growing training needs: companies, the public sector or employees? In this area, a paradigm shift, attitude and understanding of the importance of the problem are needed. The most effective form of training can be the improvement of general skills and competences both in the field of digitization and other technologies, skills, knowledge, and necessarily a company-specific training.

Increasing employment is a potential impact of the digital revolution. It is important to recognize that non-standard labor relations have already been on the rise in the past, although it is true that reducing transaction costs related to cheap access to large volumes of data and processing makes this engagement viable in new areas of business. economic activity. Accelerating globalization requires social dialogue to adapt to new decision-making structures, in which multinationals are strong players. Demographic change means difficult choices in terms of modernizing welfare state institutions and creating thousands of new and decent jobs for young workers. The potential for technological change can only be realized through the effective regulation of new forms of work and skills gaps.

The management of climate change, the development of the real economy, the creation of jobs in these priority areas for the country today, requires a broad consensus around a sustainable development strategy. Please read these instructions carefully. Prepare your manuscript exactly according to the instructions. Please use the Template, and insert the text of your paper without alter it. That is the easiest and the most efficient way to have a good published manuscript. 


\section{REFERENCES}

Ahtela, J. (2019). European Economic and Social Committee on the social dialogue for innovation in the digital economy [own-initiative opinion] (2019/C 159/01). Official Journal of the European Union. Brussels.

Dueñas Herrero, L., J. (2019). The necessary recovery of social dialogue to address regulation of the impact of new technologies on workers' rights. e-Revista Internacional de la Protección Social, 4 (2), 111-123.

European Commission. (2010). Europe 2020. A strategy for smart, sustainable and inclusive growth. Brussels

Eurostat Statistics Explained (2019). High-tech statistics - employment. Retrieved July 22, 2020, from https://ec.europa.eu/eurostat/statistics-explained/index.php?title=Archive:Hightech_statistics_-_employment\&direction=prev\&oldid=372973\#Main_statistical_findings

Global Deal. (2018). Building Trust in a Changing World of Work. The Global Deal for Decent Work and Inclusive Growth Flagship Report 2018.

Hanin, F. (2010a). Les nouveaux cadres du dialogue social: Europe et territoires, Sous la direction de Annette Jobert, Bruxelles: Peter Lang, 2008, 267 p., ISBN 978-90-5201-444-9. Relations industrielles/Industrial Relations, vol. 65, n 1, 157-159.

Hanin, F. (2010b). Les nouveaux cadres du dialogue social: Europe et territoires, Sous la direction de Annette Jobert, Bruxelles: Peter Lang, 2008, 267 p., ISBN 978-90-5201-444-9. Relations industrielles / Industrial Relations, vol. 65, n 1, 2010, 157.

International Labour Organization. (2018). Social Dialogue and the Future of Work, Report of the ILO-AICESIS Conference, 23-24 November 2017, Athens, Greece, ISBN: 978-92-2-031189-9.

Invernizzi, N., \& Foladori, G. (2010). Nanotechnology Implications for Labor, Nanotechnology Law \& Business, 7(1), 68-78.

Lucas, G., M., Boberg, J., Traum, D., Artstein, R., Gratch, J., Gainer, A., et. al. (2017). The Role of Social Dialogue and Errors in Robots, HAI '17: Proceedings of the 5th International Conference on Human Agent Interaction, 431-433, https://doi.org/10.1145/3125739.3132617.

Mexi, M. (2019). Social Dialogue and the Governance of the Digital Platform Economy: Understanding Challenges, Shaping Opportunities, Background paper for discussion at the ILO-AICESIS-CES Romania International Conference, Bucharest.

Muñoz-de-Bustillo Llorente, R. (2020). Digitalization and social dialogue: challenges, opportunities and responses. ResearchGate.

Oscar, M. \& Miguélez, F. (2013). From negotiation to imposition: Social dialogue in austerity times in Spain, Working Paper No. 51, Geneva, ILO, September 2013, ISSN 2226-7433, 2226-7840.

Romanian Government. (2018). Romania's Sustainable Development Strategy 2030. Romania.

Sadovaia, E. S. (2019) Садовая Е.С., Сауткина В.А., Зенков А.Р. Формирование новой социальной реальности: технологические вызовы. - М.: ИМЭМО РАН, 2019. ISBN 9785-9535-0564-2

United Nations (2015). Transforming our world: the 2030 Agenda for Sustainable Development.

Vogel, S. (2017). Addressing digital and technological change through social dialogue. European Foundation for the Improvement of Living and Working Conditions. 